\title{
Effects of L-carnitine against oxidative stress in human hepatocytes: involvement of peroxisome proliferator-activated receptor alpha
}

\author{
Jin-Lian Li ${ }^{1 *}$, Qiao-Yun Wang ${ }^{1}$, Hai-Yun Luan², Ze-Chun Kang ${ }^{2}$ and Chun-Bo Wang ${ }^{3}$
}

\begin{abstract}
Background: Excessive oxidative stress and lipid peroxidation have been demonstrated to play important roles in the production of liver damage. L-carnitine is a natural substance and acts as a carrier for fatty acids across the inner mitochondrial membrane for subsequent beta-oxidation. It is also an antioxidant that reduces metabolic stress in the cells. Recent years L-carnitine has been proposed for treatment of various kinds of disease, including liver injury. This study was conducted to evaluate the protective effect of L-carnitine against hydrogen peroxide $\left(\mathrm{H}_{2} \mathrm{O}_{2}\right)$-induced cytotoxicity in a normal human hepatocyte cell line, HL7702.

Methods: We analyzed cytotoxicity using MTT assay and lactate dehydrogenase (LDH) release. Antioxidant activity and lipid peroxidation were estimated by reactive oxygen species (ROS) levels, activities and protein expressions of superoxide dismutase (SOD) and catalase (CAT), and malondialdehyde (MDA) formation. Expressions of peroxisome proliferator-activated receptor (PPAR)-alpha and its target genes were evaluated by RT-PCR or western blotting. The role of PPAR-alpha in L-carnitine-enhanced expression of SOD and CAT was also explored. Statistical analysis was performed by a one-way analysis of variance, and its significance was assessed by Dennett's post-hoc test.

Results: The results showed that L-carnitine protected $\mathrm{HL} 7702$ cells against cytotoxity induced by $\mathrm{H}_{2} \mathrm{O}_{2}$. This protection was related to the scavenging of ROS, the promotion of SOD and CAT activity and expression, and the prevention of lipid peroxidation in cultured HL7702 cells. The decreased expressions of PPAR-alpha, carnitine palmitoyl transferase 1 (CPT1) and acyl-CoA oxidase (ACOX) induced by $\mathrm{H}_{2} \mathrm{O}_{2}$ can be attenuated by L-carnitine. Besides, we also found that the promotion of SOD and CAT protein expression induced by L-carnitine was blocked by PPAR-alpha inhibitor MK886.
\end{abstract}

Conclusions: Taken together, our findings suggest that L-carnitine could protect HL7702 cells against oxidative stress through the antioxidative effect and the regulation of PPAR-alpha also play an important part in the protective effect.

Keywords: L-carnitine, Hydrogen peroxide, HL7702 cells, Antioxidant effect, Peroxisome proliferator-activated receptor alpha

\section{Background}

L-carnitine (L-3-hydroxy-4-N-N-N-trimethylaminobutyrate) is an essential nutrient that the body uses to convert fat into energy. It acts as a carrier for fatty acids across the inner mitochondrial membrane for subsequent $\beta$-oxidation [1]. It is also an antioxidant that

\footnotetext{
* Correspondence: lj|813@sina.com

'Laboratory of Functional Physiology, Binzhou Medical University, Guanhai Road, Yantai, China

Full list of author information is available at the end of the article
}

reduces metabolic stress in the cells. Studies have reported that L-carnitine have an effective 1,1-diphenyl2-picryl-hydrazyl (DPPH) free radical scavenging, superoxide anion radical scavenging, hydrogen peroxide scavenging, and total reducing power [2].

Recent years L-carnitine has been proposed for treatment of various kinds of disease, including liver injury. Several studies have shown that L-carnitine administration can ameliorate or prevent liver damage of various etiologies. Animal studies showed that dietary

\section{Biomed Central}


supplementation with L-carnitine could prevent hepatitis and subsequent hepatocellular carcinoma in Long-Evans Cinnamon rats [3] and alleviate alcohol-induced liver damage in rats [4]. In addition, some experimental and clinical data suggested that early intravenous supplementation with L-carnitine could improve survival in severe valproic acid -induced hepatotoxicity [5]. In vitro, L-carnitine has been successfully used to delay the killing of cultured rat hepatocytes by 1-Methyl-4-phenyl1,2,3,6-tetrahydropyridine (MPTP) [6].

Reactive oxygen species (ROS) are considered to be involved in liver damage induced by several conditions such as alcohol abuse, fibrosis/cirrhosis of various etiologies, hepatocellular carcinoma (HCC), ischemia/reperfusion (I/R) liver injury, paracetamol overdose, and viral hepatitis [7]. Therefore, prevention or impairment of oxidative stress constitutes a therapeutic target to be achieved for hepatoprotection. Different antioxidant strategies have shown to be useful to reduce oxidative stress and cell death in hepatocytes [8]. Recently, Dobrzyńska et al. found that L-carnitine protected liver cell membranes against oxidative modifications in ethanolintoxicated rats through its ability to scavenge free radicals [9]. Therefore, antioxidant activity of L-carnitine may make it play a role in the treatment of liver diseases.

Peroxisome proliferator-activated receptors (PPARs) are ligand-activated transcription factors belonging to the nuclear hormone receptor superfamily and are involved in energy homeostasis [10]. It consists of three members: PPAR $-\alpha$, PPAR $-\gamma$, and PPAR $-\beta / \delta$. PPAR $-\alpha$ is distributed in metabolically active tissues including liver, most prominently in hepatocytes $[10,11]$. PPAR- $\alpha$ has a central role in fatty acid oxidation, lipid and lipoprotein metabolism, inflammatory responses, and oxidative stress [12]. It was reported that PPAR- $\alpha$ 'mice fed ethanol developed marked hepatomegaly, steatohepatitis, liver cell death and proliferation, and portal fibrosis [13]. PPAR- $\alpha$ ligands, such as $\mathrm{Wy}-14,643$, were reported to have an antifibrotic action in the rat thioacetamide (TAA) model of liver cirrhosis [14]. In addition, L-carnitine treatment has been found to be able to elevate PPAR- $\alpha$ activation in renal tubular cells and plays a crucial role in L-carnitine anti-apoptosis effect [15]. Therefore, we hypothesize that PPAR- $\alpha$ may mediated the hepatoprotective effect of L-carnitine.

Our work undertaken was to determine whether Lcarnitine exerts cytoprotective properties against ROSinduced cell death in cultured human hepatocytes and explores the mechanisms. For this purpose, normal human hepatocyte $\mathrm{HL} 7702$ was treated by $\mathrm{H}_{2} \mathrm{O}_{2}$, which was the major component of ROS and has been extensively used as an inducer of oxidative stress models.

\section{Methods}

\section{Reagents and drugs}

L-carnitine, $\mathrm{H}_{2} \mathrm{O}_{2}$, MTT, 2',7'-dichlorfluorescein-diacetate (DCFH-DA) and MK886 were purchased from Sigma-Aldrich (St Louis, MO, USA). Superoxide dismutase (SOD), catalase (CAT), and malonaldehyde (MDA) assay kits were all purchased from Nanjing Jiancheng Bioengineering Institute (Nanjing, China). Antibodies against PPAR- $\alpha$, SOD1, and CAT were purchased from Santa Cruz Biotechnology (Santa Cruz, CA, USA). Anti$\beta$-actin antibody was purchased from Boisynthesis Biotechnology (Beijing China). All the other reagents used were of analytical grade.

\section{Cells culture and treatment}

Human normal hepatocyte cell line HL7702 used in this study was purchased from the Shanghai Institute of Cell Biology, Chinese Academy of Sciences (Shanghai, China). Cells were cultured in RPMI 1,640 medium supplemented with $10 \%$ fetal calf serum, $100 \mathrm{U} / \mathrm{ml}$ penicillin, and $100 \mu \mathrm{g} / \mathrm{ml}$ streptomycin, and maintained at $37^{\circ}$ $\mathrm{C}$ in $5 \% \mathrm{CO}_{2}$ incubator.

To estimate the effects of L-carnitine, HL7702 cells were pretreated with various concentrations of L-carnitine for $12 \mathrm{~h}$ before exposed to $\mathrm{H}_{2} \mathrm{O}_{2}$. Then, the medium was replaced with serum-free medium and $300 \mu \mathrm{M}$ $\mathrm{H}_{2} \mathrm{O}_{2}$ was added. Control cells were received serum-free medium without $\mathrm{H}_{2} \mathrm{O}_{2}$. The cells were incubated in this condition for another $12 \mathrm{~h}$.

\section{Cell viability analysis}

Cell viability was analyzed by MTT assay. Briefly, HL7702 cells were cultured in 96-well plates at a density of $1 \times 10^{4}$ cells/well for $24 \mathrm{~h}$. L-carnitine at different concentrations $(0.01 \sim 5 \mathrm{mM})$ was added and preincubated for $12 \mathrm{~h}$ before exposed to $\mathrm{H}_{2} \mathrm{O}_{2}$. After $\mathrm{H}_{2} \mathrm{O}_{2}$ treatment as described, the medium was removed and cells were washed twice with PBS. Then, MTT $(0.5 \mathrm{mg} /$ $\mathrm{ml}$ ) was added to each well and incubation for $4 \mathrm{~h}$ at $37^{\circ} \mathrm{C}$. Finally, medium was removed and $150 \mu$ dimethyl sulfoxide (DMSO) was added to each well. The plate was read using a microplate reader (Thermo Scientific, Waltham, MA, USA) at a wavelength of $570 \mathrm{~nm}$.

\section{Measurement of lactate dehydrogenase (LDH) release}

HL7702 cells were first plated in 24-well plates for $24 \mathrm{~h}$. L-carnitine (0.1, 0.5, and $1 \mathrm{mM}$ ) was then added to the wells and preincubated for $12 \mathrm{~h}$ before exposed to $\mathrm{H}_{2} \mathrm{O}_{2}$. After $\mathrm{H}_{2} \mathrm{O}_{2}$ treatment, aliquots of culture medium were taken out for extracellular LDH activity analysis. Intracellular LDH activity was determined after lysis by addition of $1 \%$ Triton X-100. LDH activity was detected by automatic biochemical analyzer (Mindray, 
BS-200) with its commercial bio-kit at $340 \mathrm{~nm}$ according to manufacturer's protocol. LDH release represents the percentage of $\mathrm{LDH}$ in the culture medium relative to the total LDH.

Intracellular reactive oxygen species (ROS) measurement The fluorescent probe DCFH-DA was used to detect the intracellular ROS. DCFH-DA diffuses into cells and is hydrolyzed to form non-fluorescent 2',7'-dichlorodihydrofluorescein (DCFH). DCFH is then oxidised by ROS to form the highly fluorescent 2',7'-dichlorofluorescein. Following $\mathrm{H}_{2} \mathrm{O}_{2}$ treatment, cells were collected by centrifugation, resuspended in serum-free medium containing $10 \mu \mathrm{M} \mathrm{DCFH}-\mathrm{DA}$, incubated for $30 \mathrm{~min}$ at $37^{\circ} \mathrm{C}$, washed with PBS to remove unreacted dye, resuspended in PBS and was detected at $485 \mathrm{~nm}$ excitation and at $535 \mathrm{~nm}$ emission using flow cytometry.

\section{Measurement of superoxide dismutase (SOD), catalase (CAT) activity and malondialdehyde (MDA) level}

After $\mathrm{H}_{2} \mathrm{O}_{2}$ treatment, cells were resuspended in $50 \mathrm{mM}$ Tris buffer containing $0.5 \%$ Triton X-100, $\mathrm{pH} 8.0$, and lysed by freeze-thawing. Lysates were centrifuged at $5,000 \times \mathrm{g}$ for $10 \mathrm{~min}$ at $4^{\circ} \mathrm{C}$ and the supernatant obtained was used for the following measurements. The total SOD, CAT activities and MDA levels were determined spectrophotometrically using assay kits according to manufacturer's instructions. The protein content of the supernatant was determined using the Bradford method.

\section{Western blot analysis}

PPAR- $\alpha$, SOD1, and CAT protein expressions in HL7702 cells were analyzed by Western blot. Total cellular protein was extracted in lysis buffer and protein levels were quantified using a BCA (bicinchoninic acid) Protein Assay kit (Beyotime Biotechnology, Haimen, China). Aliquots containing $30 \mu \mathrm{g}$ proteins were loaded on to a $12 \%$ SDS-polyacrylamide gel. After electrophoresis, proteins were transferred to a nitrocellulose membrane. The membrane was probed with antibodies against PPAR- $\alpha$, SOD1, CAT or $\beta$-actin. The membrane was then processed with HRP conjugated goat anti-rabbit IgG (Boisynthesis Biotechnology, Beijing, China). Protein bands were visualized using the diamino-benzidine detection kit. The densities of sample bands were analyzed with Quantity One analysis software.

\section{Reverse transcriptase-PCR}

After treatment, total RNA was extracted from HL7702 cells using Trizol reagent (Biomed, Beijing, China), according to the manufacturer's protocol. Reverse transcription to cDNA was carried out with All-in-One ${ }^{\mathrm{TM}}$ First-Strand cDNA Synthesis Kit (GeneCopoeia, USA) with oligo-dT primer in a final volume of $25 \mu \mathrm{l}$ at $42^{\circ} \mathrm{C}$ for $1 \mathrm{~h}$. PCR was performed using PCR Master Mix kit (Fermentas, USA) in a final volume of $50 \mu \mathrm{l}$. The primers used were as follows: ACT CAA CAG TTT GTG GCA AGA CA and GGA AGC ACG TCC TCA CAT GA for PPAR- $\alpha$ (119 bp) [16]; GGA GAG GAG ACA GAC ACC ATC CA and CAA AAT AGG CCT GAC GAC ACC TG for CPT1 (244 bp) [17]; TGT CCT ATT TGA ACG ACC TGC CCA and AGG TTC CAA GCT ACC TCC TTG CTT for ACOX (199 bp) [18]; CGT GGA AGG ACT CAT GAC CA and TCC AGG GGT CTT ACT CCT TG for GAPDH (509 bp). Specific PCR products were visualized by agarose electrophoresis. Assessment of the amount of target gene mRNA expression was performed comparatively using GAPDH mRNA as a control.

\section{Statistical analysis}

Statistical analysis was performed by a one-way analysis of variance (ANOVA), and its significance was assessed by Dennett's post-hoc test. Data are presented as mean \pm standard deviation (SD), and a value of $P<0.05$ was considered statistically significant.

\section{Results}

L-carnitine protected $\mathrm{HL7702}$ cells against $\mathrm{H}_{2} \mathrm{O}_{2}$-induced cytotoxicity

Cell viability was evaluated by MTT assay. To determine the cytotoxicity of L-carnitine and what concentrations of L-carnitine may exert a cytoprotective effect on $\mathrm{H}_{2} \mathrm{O}_{2}$-induced toxicity in HL7702 cells, dose-viability curves were generated, as shown in Figure 1.

The upper curve in Figure 1 showed that, coincubated with L-carnitine, concentrations ranging from 0.01 to 3 $\mathrm{mM}$, cell growth were not be affected significantly, while at a higher concentration of $5 \mathrm{mM}$, a significant inhibitory effect of L-carnitine was observed $(P<0.05)$. This finding suggests that the toxicity of L-carnitine increases after $3 \mathrm{mM}$.

The lower curve in Figure 1 showed that, after exposure to $300 \mu \mathrm{M} \mathrm{H}_{2} \mathrm{O}_{2}$ for $12 \mathrm{~h}$, HL7702 cells displayed markedly decreased viability compared to untreated ones. Doses of L-carnitine ranging from 0.1 to $3 \mathrm{mM}$ significantly reduced the cell viability loss, and a dosedependent manner was found from 0.1 to $1 \mathrm{mM}$, we thus decided to use $0.1 \sim 1 \mathrm{mM}$ for all subsequent experiments.

\section{L-carnitine inhibited $\mathrm{H}_{2} \mathrm{O}_{2}$-induced $\mathrm{LDH}$ release in $\mathrm{HL7702}$} cells

The integrity of cell membrane was determined by the release of LDH. Figure 2 showed that there was a low LDH leakage ratio under normal conditions. However, $\mathrm{H}_{2} \mathrm{O}_{2}$ induced significant LDH release. Pretreatment 


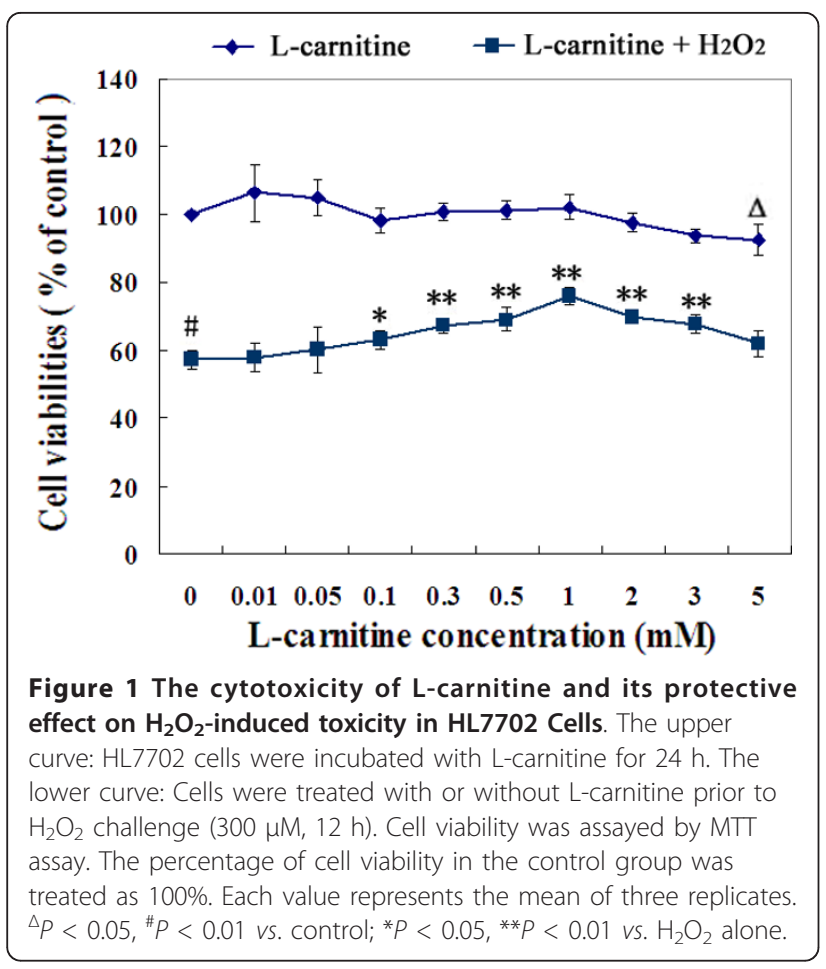

with $0.1 \sim 1 \mathrm{mM}$ L-carnitine reduced $\mathrm{H}_{2} \mathrm{O}_{2}$-induced $\mathrm{LDH}$ release in a dose-dependent manner.

\section{L-carnitine promoted endogenous antioxidant defense in} HL7702 cells under oxidative stress

SOD, CAT activities and protein levels were measured to investigate the antioxidative effect of L-carnitine on $\mathrm{H}_{2} \mathrm{O}_{2}$-damaged HL7702 cells. The activity was expressed as $\mathrm{U} / \mathrm{mg}$ protein in cells. Compared with the control group, the activities of total SOD and CAT in the $\mathrm{H}_{2} \mathrm{O}_{2}$

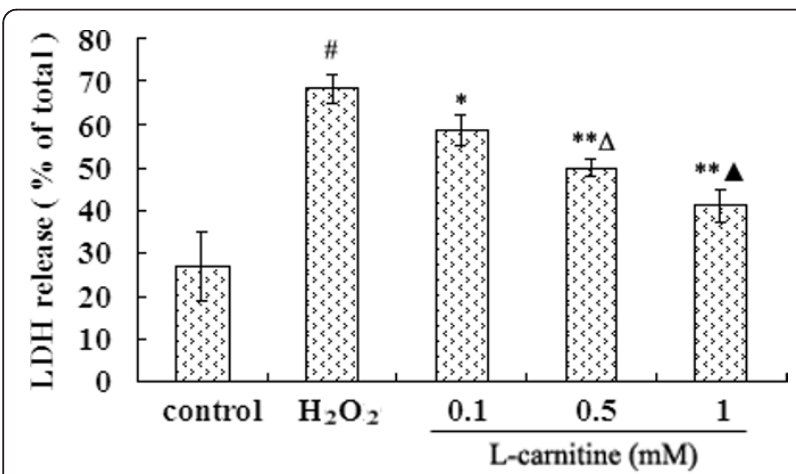

Figure 2 Effect of L-carnitine on the LDH release of HL7702 cells. Cells were treated with or without $\mathrm{L}$-carnitine prior to $\mathrm{H}_{2} \mathrm{O}_{2}$ challenge ( $300 \mu \mathrm{M}, 12 \mathrm{~h}$ ). LDH release represents the percentage of $\mathrm{LDH}$ in the culture medium relative to the total $\mathrm{LDH}$. Each value represents the mean of three replicates. ${ }^{\#} P<0.01$ vs. control; ${ }^{*} P<$ 0.05 , ${ }^{*} \mathrm{P}<0.01$ vs. $\mathrm{H}_{2} \mathrm{O}_{2}$ alone; ${ }^{\Delta} P<0.05$ vs. $0.1 \mathrm{mM} \mathrm{L}$-carnitine; ${ }^{\wedge} P$ $<0.05$ vs. $0.5 \mathrm{mM}$ L-carnitine. alone group were decreased by $30.05 \%$ and $38.25 \%$ respectively (Figure $3 \mathrm{~A}$ ). Compared to $\mathrm{H}_{2} \mathrm{O}_{2}$-damaged cells, $0.5 \sim 1 \mathrm{mM} \mathrm{L}$-carnitine reversed the activities of SOD and CAT. Western blot analysis showed that $\mathrm{H}_{2} \mathrm{O}_{2}$ exposure resulted in a marked decrease of $\mathrm{Cu}, \mathrm{Zn}-\mathrm{SOD}$ and CAT protein levels in HL7702 cells, while L-carnitine pretreatment significantly elevated the protein levels (Figure 3B).

\section{L-carnitine scavenged $\mathrm{H}_{2} \mathrm{O}_{2}$-induced ROS production in HL7702 cells}

To determine whether L-carnitine prevents $\mathrm{H}_{2} \mathrm{O}_{2}$ induced ROS generation, the concentration of intracellular ROS was evaluated by the changes in DCF fluorescence intensity. The result showed that DCF fluorescence intensity dropped significantly from $23.1 \pm$ 2.0 in cells treated with $\mathrm{H}_{2} \mathrm{O}_{2}$ only to values between $16.9 \pm 1.3$ and $12.8 \pm 1.3$ in cells to which $0.1 \sim 1 \mathrm{mM}$ L-carnitine was added (Figure 4).

\section{L-carnitine inhibited lipid peroxidation in $\mathrm{H}_{2} \mathrm{O}_{2}$-damaged HL7702 cells}

The ability of L-carnitine to inhibit lipid peroxidation in $\mathrm{H}_{2} \mathrm{O}_{2}$-treated HL7702 cells was also tested by determining MDA levels. As shown in Figure 5, the exposure of cells to $\mathrm{H}_{2} \mathrm{O}_{2}$ increased MDA levels by approximately 1.7 fold relative to control cells. An obvious dose-dependent reduction of L-carnitine on MDA levels in $\mathrm{H}_{2} \mathrm{O}_{2}$ treated cells was observed.

\section{L-carnitine up-regulated PPAR- $\alpha$ expression in $\mathrm{H}_{2} \mathrm{O}_{2-}$ damaged HL7702 cells}

We further analyzed the effect of L-carnitine on PPAR$\alpha$ mRNA and protein expressions in $\mathrm{H}_{2} \mathrm{O}_{2}$-treated HL7702 cells. As shown in Figure 6, treatment of HL7702 cells with $300 \mu \mathrm{M} \mathrm{H}_{2} \mathrm{O}_{2}$ for $12 \mathrm{~h}$ reduced the PPAR- $\alpha$ mRNA and protein levels in HL7702 cells. When the cells were preincubated with L-carnitine before $\mathrm{H}_{2} \mathrm{O}_{2}$ exposure, PPAR- $\alpha$ expression increased markedly compared to $\mathrm{H}_{2} \mathrm{O}_{2}$ alone group, although the mRNA expression was not significantly changed in 0.1 mM L-carnitine group.

To assess if the elevated PPAR- $\alpha$ expression by L-carnitine leads to induction of PPAR- $\alpha$-regulated genes in $\mathrm{H}_{2} \mathrm{O}_{2}$-treated HL7702 cells, we examined mRNA levels of CPT1 and ACOX by RT-PCR. Exposure to $\mathrm{H}_{2} \mathrm{O}_{2}$ caused inhibition of the mRNA expression of CPT1 and ACOX. L-carnitine, on the other hand, attenuated the inhibitory effect of $\mathrm{H}_{2} \mathrm{O}_{2}$.

L-carnitine increases SOD and CAT expression in $\mathrm{H}_{2} \mathrm{O}_{2}-$ damaged HL7702 cells via PPAR- $\alpha$ expression

Activation of PPAR- $\alpha$ by agonists has been previously shown to enhance SOD expression and CAT activity in 

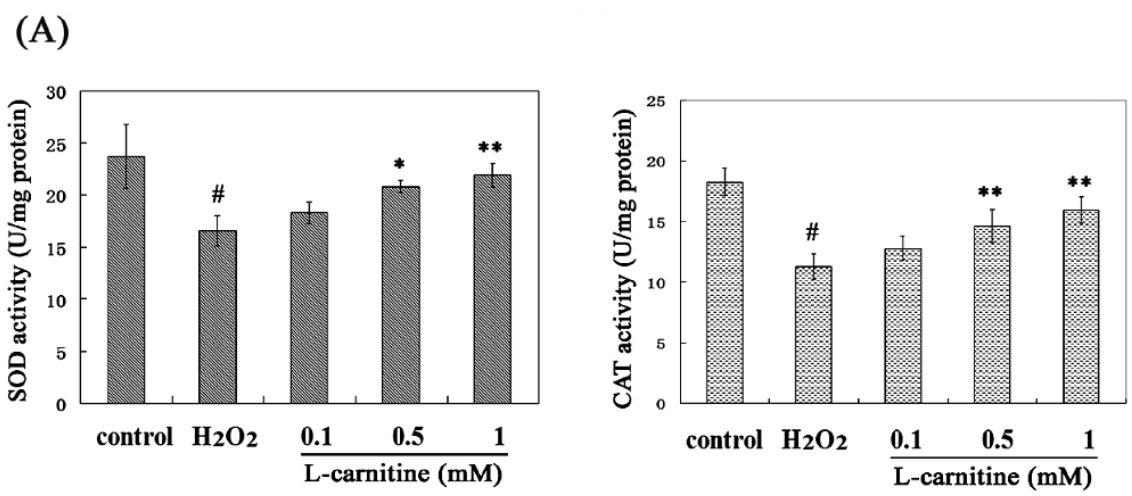

(B)
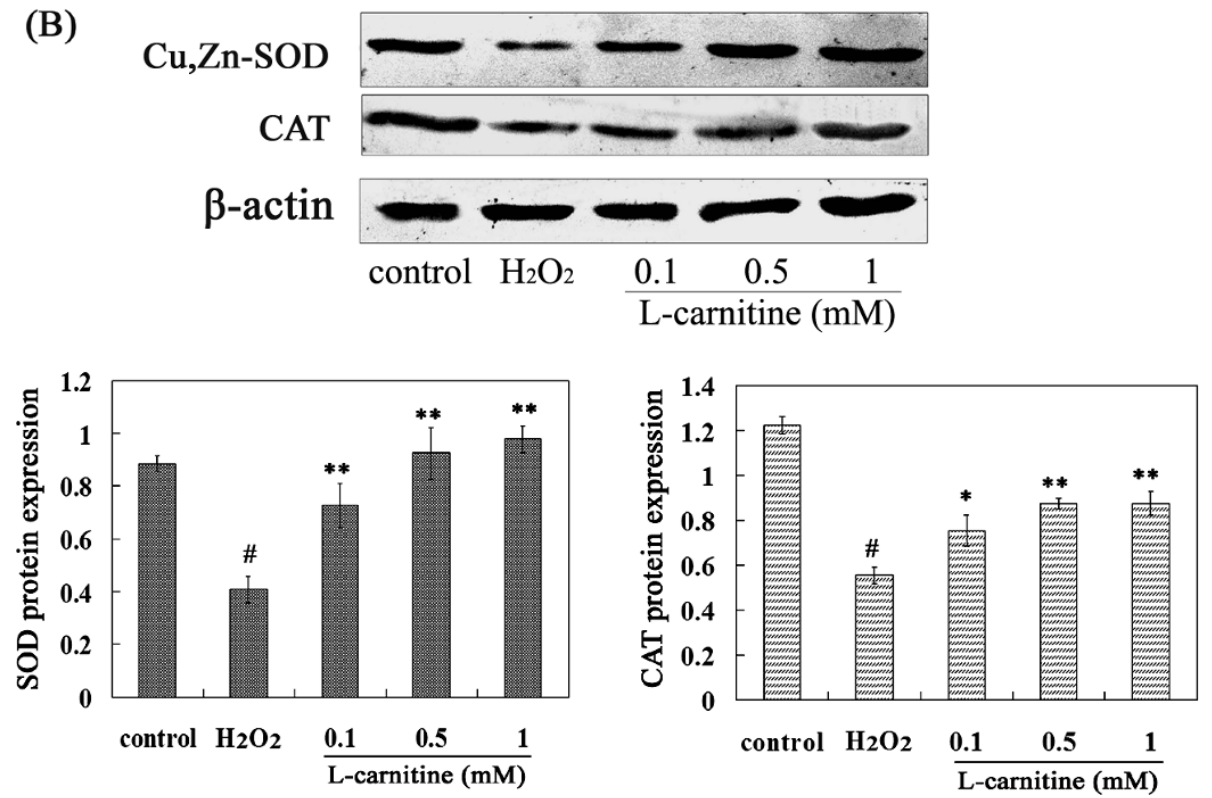

Figure 3 Effect of L-carnitine on the activities and protein expressions of SOD and CAT in $\mathrm{H}_{2} \mathrm{O}_{2}$-damaged HL7702 cells. Cells were treated with L-carnitine for $12 \mathrm{~h}$ and followed by the treatment of $\mathrm{H}_{2} \mathrm{O}_{2}(300 \mu \mathrm{M})$ for $12 \mathrm{~h}$. A: Total SOD and CAT activities were calculated in units of activity per mg of total protein. B: $\mathrm{Cu}, \mathrm{Zn}$-SOD and CAT expressions were determined by western blot analysis. Results were expressed as the ratio of expression level of $\mathrm{Cu}, \mathrm{Zn}-\mathrm{SOD}$ or CAT over $\beta$-actin. Each value represents the mean of three replicates. ${ }^{\#} P<0.01$ vs. control; ${ }^{*} P<$ $0.05,{ }^{*} \mathrm{P}<0.01$ vs. $\mathrm{H}_{2} \mathrm{O}_{2}$ alone.
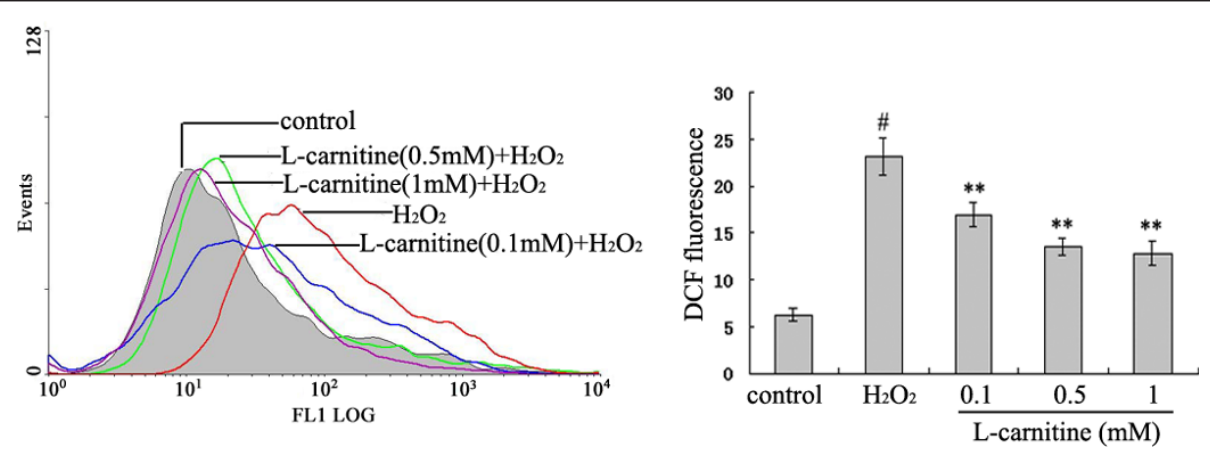

Figure 4 Effect of L-carnitine on intracellular ROS levels after $\mathrm{H}_{2} \mathrm{O}_{2}$ exposure in $\mathrm{HL7702}$ cells. Cells were treated with or without $\mathrm{L}$ carnitine prior to $\mathrm{H}_{2} \mathrm{O}_{2}$ challenge $(300 \mu \mathrm{M}, 12 \mathrm{~h})$. ROS levels were measured using fluorescent probe DCFH-DA. Each value represents the mean of three replicates. ${ }^{\#} P<0.01$ vs. control; ${ }^{*} P<0.01$ vs. $\mathrm{H}_{2} \mathrm{O}_{2}$ alone. 


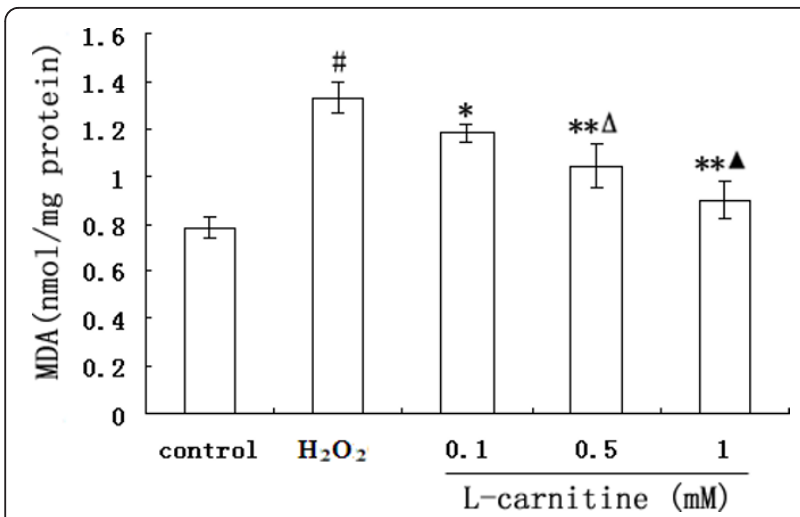

Figure 5 Effect of L-carnitine on $\mathrm{H}_{2} \mathrm{O}_{2}$-induced MDA formation in $\mathrm{HL7702}$ cells. Cells were treated with or without $\mathrm{L}$-carnitine prior to $\mathrm{H}_{2} \mathrm{O}_{2}$ challenge $(300 \mu \mathrm{M}, 12 \mathrm{~h})$. Each value represents the mean of three replicates. ${ }^{\#} P<0.01$ vs. control; ${ }^{*} P<0.05$, ${ }^{*} P<0.01$ vs. $\mathrm{H}_{2} \mathrm{O}_{2}$ alone; ${ }^{\triangle} P<0.05$ vs. $0.1 \mathrm{mM} \mathrm{L}$-carnitine; ${ }^{\wedge} P<0.05$ vs. $0.5 \mathrm{mM} \mathrm{L-}$ carnitine.

the liver $[19,20]$. In order to investigate whether the elevated SOD and CAT expression induced by L-carnitine was due to enhanced levels of PPAR- $\alpha$, a specific antagonist of PPAR- $\alpha$, MK886, was used. MK886 (5 $\mu \mathrm{M}$ ) was added to cells $2 \mathrm{~h}$ prior to $\mathrm{H}_{2} \mathrm{O}_{2}$ insult. As shown in Figure 7, MK886 did not alter SOD and CAT protein levels in control cells. However, the up-regulation of SOD and CAT expression by L-carnitine was inhibited by addition of MK886 in $\mathrm{H}_{2} \mathrm{O}_{2}$-treated cells.

\section{Discussion}

$\mathrm{H}_{2} \mathrm{O}_{2}$ is a major component of ROS produced intracellularly during many physiological and pathological processes, and causes oxidative damage. It has been extensively used as an inducer of oxidative stress in vitro models. Our results showed that $300 \mu \mathrm{M} \mathrm{H} \mathrm{H}_{2} \mathrm{O}_{2}$ exposure for $12 \mathrm{~h}$ induced a significantly decreased cell growth and elevated LDH leakage in HL7702 cells. Lcarnitine at a concentration of 0.1 to $3 \mathrm{mM}$ showed no harmful effects on the growth of HL7702 cells, however, cell growth was inhibited by $5 \mathrm{mM} \mathrm{L}$-carnitine. The possibility may be that high doses of carnitine possess pro-oxidant activity as has been reported [21]. Our results demonstrated the protective effects of $0.1 \sim 3$ $\mathrm{mM}$ L-carnitine against the inhibition of cell growth induced by $\mathrm{H}_{2} \mathrm{O}_{2}$. LDH leakage was also inhibited by 0.1 $\sim 1 \mathrm{mM} \mathrm{L}$-carnitine in a dose-dependent manner. These findings suggest that L-carnitine is capable of reducing $\mathrm{H}_{2} \mathrm{O}_{2}$-induced cytotoxicity in HL7702 cells.

Oxidative stress after $\mathrm{H}_{2} \mathrm{O}_{2}$ exposure results from intracellular ROS production and decreased ROS scavenging. To further explore the mechanism of the protective effect of L-carnitine on $\mathrm{H}_{2} \mathrm{O}_{2}$-induced oxidative damage in HL7702 cells, we examined the effect of
L-carnitine on intracellular ROS production. $\mathrm{H}_{2} \mathrm{O}_{2}$ challenge caused an apparent increase in ROS levels in HL7702 cells compared to control group, however, in vitro treatment with $\mathrm{L}$-carnitine resulted in reduced ROS levels. Scavenging of ROS is determined by antioxidant enzymes such as SOD and CAT. CAT is considered to be the most relevant enzyme involved in detoxification of $\mathrm{H}_{2} \mathrm{O}_{2}$ and protection of hepatocytes from oxidative stress [22]. We observed that the inhibited activities and expressions of SOD and CAT induced by $\mathrm{H}_{2} \mathrm{O}_{2}$ were attenuated by L-carnitine. These observations supported the idea that L-carnitine did protect HL7702 cells from $\mathrm{H}_{2} \mathrm{O}_{2}$-induced cytotoxicity by its antioxidant property.

Liver damage was associated with enhanced lipid peroxidation and formation of lipid radicals [23,24]. MDA, as an end product of lipid peroxidation, usually used to estimate the extent of lipid peroxidation. It has been shown that many pathological conditions that resulted in elevation of MDA due to lipid peroxidation were prevented by L-carnitine $[25,26]$. In our paper, MDA levels in HL7702 cells increased after $\mathrm{H}_{2} \mathrm{O}_{2}$ exposure. However, pretreatment with L-carnitine $(0.1 \sim 1 \mathrm{mM})$ prevented a further increase in MDA levels.

$\mathrm{H}_{2} \mathrm{O}_{2}$, a low molecular weight compound, can easily penetrate lipid membrane, cause lipid peroxidation, and disturb lipid homeostasis. PPAR- $\alpha$ is a ligand-dependent transcription factor that is known to have critical roles in the regulation of lipid homeostasis. It has been reported that PPAR- $\alpha$ expression decreased in a rat model of nonalcoholic fatty liver disease [27] and the absence of PPAR- $\alpha$ have been demonstrated to cause lipid accumulation in liver of rats [28]. Our results showed that HL7702 cells exposed to $300 \mu \mathrm{M} \mathrm{H}_{2} \mathrm{O}_{2}$ for $12 \mathrm{~h}$ showed a significant reduction in PPAR- $\alpha$ expression levels, indicating the disturbed lipid homeostasis might occur in $\mathrm{H}_{2} \mathrm{O}_{2}$-damaged HL7702 cells. However, L-carnitine pretreatment attenuated the inhibitory effect of $\mathrm{H}_{2} \mathrm{O}_{2}$ on the expression of PPAR- $\alpha$. It is well known that expression of a range of genes involved in lipid homeostasis is controlled by PPAR- $\alpha$, which binds to the peroxisome proliferator response element (PPRE) in the promoters of these genes [29]. Therefore, mRNA expression of CPT1 and ACOX, two PPAR- $\alpha$ target genes that control fatty acid oxidation [30,31], were also investigated. Results showed that the repression of CPT1 and ACOX expression induced by $\mathrm{H}_{2} \mathrm{O}_{2}$ were all attenuated by L-carnitine. Above observations indicate that the disturbed lipid homeostasis induced by $\mathrm{H}_{2} \mathrm{O}_{2}$ might be ameliorated by $\mathrm{L}$-carnitine by increasing PPAR- $\alpha$ expression. In fact, as we know, L-carnitine acts as a carrier participate in fatty acids $\beta$-oxidation. So, the attenuated lipid metabolism in $\mathrm{H}_{2} \mathrm{O}_{2}$-damaged HL7702 cells would be significantly ameliorated by L-carnitine. This observation is consistent 


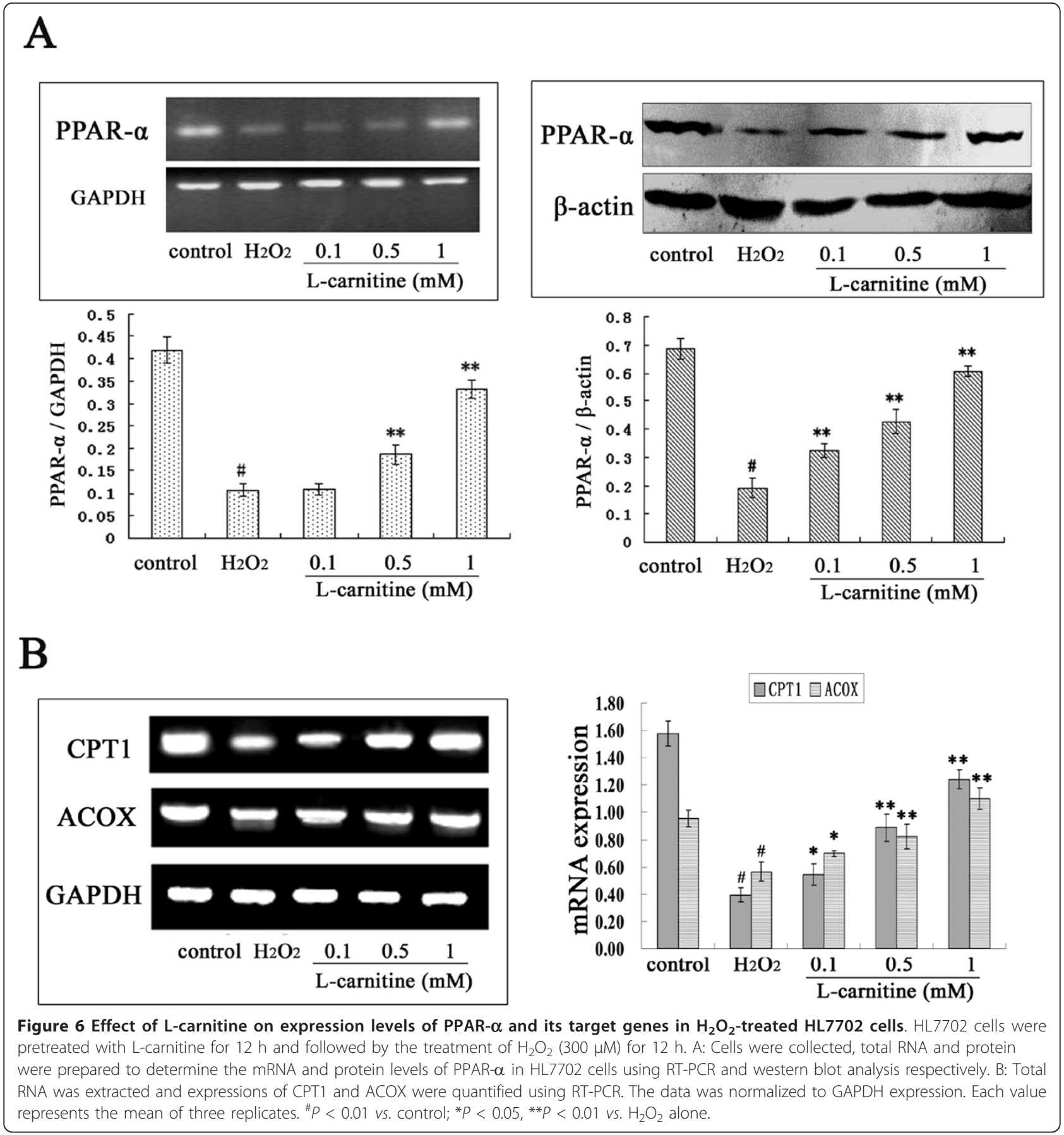

with a recent study, which demonstrated that L-carnitine supplementation induced recovery of liver lipid metabolism in cachectic animals [32]. Furthermore, it is likely that the enhancement of $\beta$-oxidation induced by L-carnitine would generate ATP, thereby reversing $\mathrm{H}_{2} \mathrm{O}_{2}$ initiated depletion of ATP in cells and attenuating cell injury. ATP was considered to be a critical event in lethal cell injury produced by oxygen radicals [33]. The hypotheses need further investigation.
It has been reported that PPAR- $\alpha$ gene expression is associated with SOD gene expression in the liver [20], and CAT has been identified as one of the target enzymes of PPAR- $\alpha$ [34]. In the present study, the upregulation of SOD and CAT expression by L-carnitine were attenuated by PPAR- $\alpha$ antagonist MK886. The results reveal the crucial role of PPAR- $\alpha$ activation in the protective effect of L-carnitine against $\mathrm{H}_{2} \mathrm{O}_{2}$-induced damage in HL7702 cells. L-carnitine might elevate 


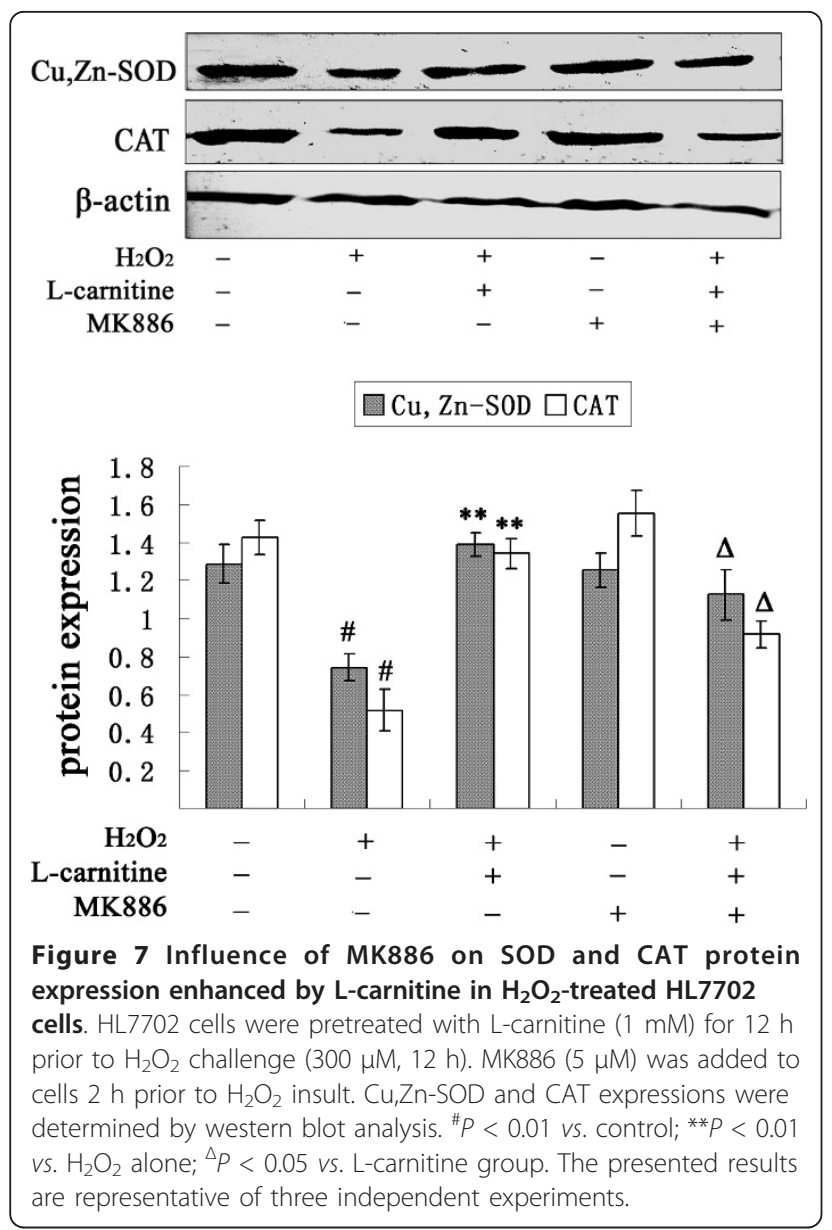

PPAR- $\alpha$ expression, and then activate SOD and CAT, resulting in a decrease in extracellular $\mathrm{H}_{2} \mathrm{O}_{2}$ levels and prevention of liver damage.

\section{Conclusions}

Taken together, the present results provide evidence that L-carnitine prevented in vitro human hepatocyte oxidative stress induced by $\mathrm{H}_{2} \mathrm{O}_{2}$. The protective effects of L-carnitine observed in the current paper can possibly be mediated through its antioxidant potential. The elevated PPAR- $\alpha$ expression by L-carnitine play an important part in the protective effect, which might contribute to the amelioration of lipid homeostasis, the improvement of antioxidant ability, and increased ATP in L-carnitine treated cells.

\section{Abbreviations}

$\mathrm{H}_{2} \mathrm{O}_{2}$ : Hydrogen peroxide; MTT: 3-[4,5-dimethylthiazol-2-yl]-2,5diphenyltetrazolium bromide; LDH: Lactate dehydrogenase; ROS: Reactive oxygen species; SOD: Superoxide dismutase; CAT: Catalase; MDA: Malondialdehyde; PPAR: Peroxisome proliferator-activated receptor; CPT1: Carnitine palmitoyl transferase 1; ACOX: Acyl-CoA oxidase; DPPH: 1,1diphenyl-2-picryl-hydrazyl; DCFH-DA: 2,7-dichlorofluorescein diacetate; DMSO: Dimethyl sulfoxide.

\section{Acknowledgements}

This work was supported by Shandong Provincial Natural Science Foundation, China (Grant No. ZR2010HL068).

\section{Author details}

'Laboratory of Functional Physiology, Binzhou Medical University, Guanhai Road, Yantai, China. ${ }^{2}$ Department of Pharmacology, Binzhou Medical University, Guanhai Road, Yantai, China. ${ }^{3}$ Medical College, Qingdao University, Ningxia Road, Qingdao, China.

\section{Authors' contributions}

$J L L$ designed, carried out the experiment and drafted the manuscript. QYW and HYL participated in the design and coordination of this study, and performed experiments. ZCK performed the partial experiments and analyzed data. CBW participated in the analysis and interpretation of data. All authors read and approved the final manuscript.

\section{Competing interests}

The authors declare that they have no competing interests.

Received: 3 January 2012 Accepted: 21 March 2012

Published: 21 March 2012

\section{References}

1. Rebouche CJ: Kinetics, pharmacokinetics, and regulation of L-carnitine and acetyl-L-carnitine metabolism. Ann N Y Acad Sci 2004, 1033:30-41.

2. Gülçin I: Antioxidant and antiradical activities of L-carnitine. Life Sci 2006, 78:803-811.

3. Chang B, Nishikawa M, Nishiguchi S, Inoue M: L-carnitine inhibits hepatocarcinogenesis via protection of mitochondria. Int J Cancer 2005, 113:719-729.

4. Bykov I, Järveläinen $H$, Lindros $K$ : L-carnitine alleviates alcohol-induced liver damage in rats: role of tumour necrosis factor-alpha. Alcohol Alcohol 2003, 38:400-406.

5. Lheureux PE, Hantson P: Carnitine in the treatment of valproic acidinduced toxicity. Clin Toxicol (Phila) 2009, 47:101-111.

6. Snyder JW, Kyle ME, Ferraro TN: L-carnitine delays the killing of cultured hepatocytes by 1-methyl-4-phenyl-1,2,3,6-tetrahydropyridine. Arch Biochem Biophys 1990, 276:132-138.

7. Pablo M: Role of free radicals in liver diseases. Hepatol Int 2009, 3:526-536.

8. Medina J, Moreno-Otero R: Pathophysiological basis for antioxidant therapy in chronic liver disease. Drugs 2005, 65:2445-2461.

9. Dobrzyńska I, Szachowicz-Petelska B, Skrzydlewska E, Figaszewski Z: Effect of L-carnitine on liver cell membranes in ethanol-intoxicated rats. Chem Biol Interact 2010, 188:44-51.

10. Issemann I, Green S: Activation of a member of the steroid hormone receptor superfamily by peroxisome proliferators. Nature 1990, 347:645-650.

11. Braissant O, Foufelle F, Scotto C, Dauça M, Wahli W: Differential expression of peroxisome proliferator-activated receptors (PPARs): tissue distribution of PPAR-alpha, -beta, and -gamma in the adult rat. Endocrinology 1996, 137:354-366.

12. Burri $\mathrm{L}$, Thoresen $\mathrm{GH}$, Berge RK: The role of PPARa activation in liver and muscle. PPAR Research 2010, 2010:pii: 542359.

13. Nakajima T, Kamijo Y, Tanaka N, Sugiyama E, Tanaka E, Kiyosawa K, Fukushima Y, Peters JM, Gonzalez FJ, Aoyama T: Peroxisome proliferatoractivated receptor-alpha protects against alcohol-induced liver damage. Hepatology 2004, 40:972-980.

14. Toyama T, Nakamura H, Harano Y, Yamauchi N, Morita A, Kirishima T, Minami M, Itoh $Y$, Okanoue T: PPARalpha ligands activate antioxidant enzymes and suppress hepatic fibrosis in rats. Biochem Biophys Res Commun 2004, 324:697-704.

15. Chen HH, Sue YM, Chen CH, Hsu YH, Hou CC, Cheng CY, Lin SL, Tsai WL, Chen TW, Chen TH: Peroxisome proliferator-activated receptor alpha plays a crucial role in L-carnitine anti-apoptosis effect in renal tubular cells. Nephrol Dial Transplant 2009, 24:3042-3049.

16. Cardell LO, Hägge M, Uddman R, Adner M: Downregulation of peroxisome proliferator-activated receptors (PPARs) in nasal polyposis. Respir Res 2005, 6:132.

17. Shimoda H, Tanaka J, Kikuchi M, Fukuda T, Ito H, Hatano T, Yoshida T: Effect of polyphenol-rich extract from walnut on diet-induced 
hypertriglyceridemia in mice via enhancement of fatty acid oxidation in the liver. J Agric Food Chem 2009, 57:1786-1792.

18. Bjork JA, Wallace KB: Structure-activity relationships and human relevance for perfluoroalkyl acid-induced transcriptional activation of peroxisome proliferation in liver cell cultures. Toxicol Sci 2009, 111:89-99.

19. Berger J, Moller DE: The mechanisms of action of PPARs. Annu Rev Med 2002, 53:409-435.

20. Inoue I, Noji S, Awata T, Takahashi K, Nakajima T, Sonoda M, Komoda T, Katayama S: Bezafibrate has an antioxidant effect: peroxisome proliferator-activated receptor alpha is associated with $\mathrm{Cu} 2+, \mathrm{Zn} 2$ +-superoxide dismutase in the liver. Life Sci 1998, 63:135-144.

21. Hu ML, Chen YK, Lin YF: The antioxidant and prooxidant activity of some B vitamins and vitamin-like compounds. Chem Biol Interact 1995, 97:63-73.

22. De Bleser PJ, Xu G, Rombouts K, Rogiers V, Geerts A: Glutathione levels discriminate between oxidative stress and transforming growth factorbeta signaling in activated rat hepatic stellate cells. J Biol Chem 1999, 274:33881-33887.

23. Tsukamoto H, Lu SC: Current concepts in the pathogenesis of alcoholic liver injury. FASEB J 2001, 15:1335-1349.

24. Lu Y, Cederbaum Al: CYP2E1 and oxidative liver injury by alcohol. Free Radic Biol Med 2008, 44:723-738.

25. Derin N, Agac A, Bayram Z, Asar M, Izgut-Uysal VN: Effects of L-carnitine on neutrophil-mediated ischemia-reperfusion injury in rat stomach. Cell Biochem Funct 2006, 24:437-442.

26. Atila K, Coker A, Sagol O, Coker I, Topalak O, Astarcioglu H, Karademir S, Astarcioglu I: Protective effects of carnitine in an experimental ischemiareperfusion injury. Clin Nutr 2002, 21:309-313.

27. Yeon JE, Choi KM, Baik SH, Kim KO, Lim HJ, Park KH, Kim JY, Park JJ, Kim JS, Bak YT, Byun KS, Lee CH: Reduced expression of peroxisome proliferatoractivated receptor-a may have an important role in the development of non-alcoholic fatty liver disease. J Gastroenterol Hepatol 2004, 19:799-804.

28. Leone TC, Weinheimer CJ, Kelly DP: A critical role for the peroxisome proliferator-activated receptor a (PPARa) in the cellular fasting response: the PPARa-null mouse as a model of fatty acid oxidation disorders. Proc Natl Acad Sci USA 1999, 96:7473-7478.

29. Lemberger T, Desvergne B, Wahli W: Peroxisome proliferator activated receptors: a nuclear receptor signaling pathway in lipid physiology. Annu Rev Cell Dev Biol 1996, 12:335-363.

30. McGarry JD, Brown NF: The mitochondrial carnitine palmitoyltransferase system: from concept to molecular analysis. Eur J Biochem 1997, 244:1-14.

31. Qi C, Zhu Y, Reddy JK: Peroxisome proliferator-activated receptors, coactivators, and downstream targets. Cell Biochem Biophys 2000, 32:187-204.

32. Silvério R, Laviano A, Fanelli FR, Seelaender M: L-Carnitine induces recovery of liver lipid metabolism in cancer cachexia. Amino Acids 2011.

33. Hyslop PA, Hinshaw DB, Halsey WA Jr, Schraufstätter IU, Sauerheber RD, Spragg RG, Jackson JH, Cochrane CG: Mechanisms of oxidant-mediated cell injury. The glycolytic and mitochondrial pathways of ADP phosphorylation are major intracellular targets inactivated by hydrogen peroxide. J Biol Chem 1988, 263:1665-1675.

34. Girnun GD, Domann FE, Moore SA, Robbins ME: Identification of a functional peroxisome proliferator-activated receptor response element in the rat catalase promoter. Mol Endocrinol 2002, 16:2793-2801.

doi:10.1186/1423-0127-19-32

Cite this article as: Li et al:: Effects of L-carnitine against oxidative stress in human hepatocytes: involvement of peroxisome proliferatoractivated receptor alpha. Journal of Biomedical Science 2012 19:32.

\section{Submit your next manuscript to BioMed Central and take full advantage of:}

- Convenient online submission

- Thorough peer review

- No space constraints or color figure charges

- Immediate publication on acceptance

- Inclusion in PubMed, CAS, Scopus and Google Scholar

- Research which is freely available for redistribution

Submit your manuscript at www.biomedcentral.com/submit
Ciomed Central 